\begin{abstract}
Iranica
Abstracta Iranica Revue bibliographique pour le domaine irano-aryen

Volume 32-33 | 2013

Comptes rendus des publications de 2009-2010
\end{abstract}

\title{
Daniel T. Potts. Elamite Temple Building
}

\section{Rémy Boucharlat}

\section{(2) OpenEdition}

Journals

Édition électronique

URL : http://journals.openedition.org/abstractairanica/40135

DOI : 10.4000/abstractairanica.40135

ISSN : 1961-960X

Éditeur :

CNRS (UMR 7528 Mondes iraniens et indiens), Éditions de l'IFRI

Édition imprimée

Date de publication : 1 décembre 2013

ISSN : 0240-8910

\section{Référence électronique}

Rémy Boucharlat, « Daniel T. Potts. Elamite Temple Building », Abstracta Iranica [En ligne], Volume 32-33 | 2013, document 24, mis en ligne le 01 juillet 2016, consulté le 02 octobre 2020. URL : http:// journals.openedition.org/abstractairanica/40135; DOI : https://doi.org/10.4000/abstractairanica. 40135

Ce document a été généré automatiquement le 2 octobre 2020.

Tous droits réservés 


\title{
Daniel T. Potts. Elamite Temple Building
}

\author{
Rémy Boucharlat
}

\section{RÉFÉRENCE}

«Elamite Temple Building », in : Mark J. Boda and Jamie Novotny, eds., From the Foundations to the Crenellations, Essays on Temple Building in the Ancient Near East and Hebrew Bible. Münster, Ugarit-Verlag, 2010, p. 49-70 and Appendix 2: Catalogue of Elamite Sources, p. 479-509. (AOAT Bd. 366)

1 L'A. a rassemblé l'information sur les sanctuaires élamites, moins par les vestiges, très peu nombreux en dehors de Suse, que les témoins que sont les briques inscrites retrouvées sur une dizaine de sites dans le Hūzestān et quatre dans le Fārs et près du golfe Persique. De plus en plus, on sait l'importance des traditions élamites qui se sont maintenues dans le Fars comme dans la plaine à l'époque achéménide (cf. en particulier la synthèse de W. Henkelman, c.r. $\mathrm{n}^{\circ} 76$ ). C'est pourquoi l'apport de cet article est appréciable. Il donne les différentes désignations des temples et les termes de construction, les types de temples et leur environnement, peut-être associés à un jardin, renseignements que peut donner le texte des briques. Le copieux catalogue présente les sources selon l'ordre chronologique entre la fin $\mathrm{du} 3^{\mathrm{e}}$ mill. et la période Néo-Elamite III, au VII $\mathrm{e}$. av. n.è. 


\section{AUTEURS}

RÉMY BOUCHARLAT

CNRS, Lyon 